\title{
Age-related Differences in Confrontation Naming Ability according to Visual Stimulus Valence
}

\author{
Shin Hee Kim, Jee Eun Sung \\ Department of Communication Disorders, Ewha Womans University, Seoul, Korea
}

Correspondence: Jee Eun Sung, PhD Department of Communication Disorders, Ewha Womans University, 52 Ewhayeodae-gil, Seodaemun-gu, Seoul 03760, Korea

Tel: $+82-2-3277-2208$

Fax: +82-2-3277-2122

E-mail: jeesung@ewha.ac.kr

Received: April 5, 2021

Revised: April 24, 2021

Accepted: April 24, 2021

This work was supported by the Ministry of Education of the Republic of Korea and National Research Foundation of Korea (NRF-

2019R1A2C1089280)

This article is a revision of the first author's master's thesis.

\begin{abstract}
Objectives: The purpose of this study is to examine the effects of emotions on the confrontation naming of healthy elders and young adults. Methods: The study had a total of 60 subjects (30 elders and 30 young adults). In the confrontation naming task, the researcher asked the subjects to say the name of the picture presented on a screen as quickly and accurately as possible. Results: First, the results of the study showed significantly lower accuracy in the elders compared to the young adults and a significant difference in accuracy according to emotional valence. There was a significant difference between positive and neutral emotional valance and between negative and neutral emotional valance. Additionally, the interaction between the group and emotional valence was statistically significant. The post-hoc test showed that the naming accuracy of the elders was lower than that of the young in the negative emotional valance. Secondly, elders had a longer response time than the young adults. Also, there was a significant difference in response time according to emotional valence. There was a significant difference in response time in three emotional valences (positive, negative, neutral), and the response time increased in neutral < positive $<$ negative. Finally, the interaction between the group and emotional valence was statistically significant, which attributed to the longer response time of the elders compared to the young adults in the positive and negative emotional valance. Conclusion: The study results suggest that emotional valence may interfere with word production, and that such interference may be greater for the elderly than for the young.
\end{abstract}

Keywords: Naming ability, IAPS, Emotional valence, Aging
급격히 증가하는 고령층의 인구수에 따라, 이들의 심리 및 신체 적 변화 그리고 사회경제적 능력의 시대적 변화 등과 맞물려 노년 층의 인지 및 언어 능력과 관련된 연구에 대한 관심이 증가하고 있 다(Kim, Hwang, Kim, \& Kim, 2013). 이러한 시대적 흐름에 따라 노화에 따른 의사소통 능력의 변화를 파악하는 것이 필요하다. 노 년층의 경우, 노화에 따른 언어 문제로 가장 흔하게 언급되는 것이 노화에 따른 이름대기 손상이다(Kim et al., 2013; Ramsay, Nicholas, Au, Obler, \& Albert, 1999; Sung \& Kim, 2011). 노년층은 연령 이 증가할수록 저빈도 단어나 고유명사를 산출할 때 어려움을 겪 거나 의미착어를 보이고(Burda, 2011; Mortensen, Meyer, \& Humphreys, 2006) 단어재인 및 처리 속도가 늦어지는 것으로 보고된다 (Ratcliff, Thapar, Gomez, \& McKoon, 2004). 또한 대면이름대기 과 제에서의 수행력 저하와 반응시간의 증가, 즉 느린 산출 속도를 보
인다고 보고된다(Barresi, Nicholas, Connor, Obler, \& Albert, 2000; Feyereisen, 1997; Kim et al., 2013; Mortensen et al., 2006; Nicholas, Obler, Albert, \& Goodglass, 1985; Ramsay et al., 1999; Schmitter-Edgecombe, Vesneski, \& Jones, 2000). 이러한 이름대기 어려움 은 노인들에게 당혹감을 주는 것으로 보고되고 있다(Brown \& McNeill, 1966; Lovelace \& Twohig, 1990). 이름대기 처리 과정은 지 각, 주의집중, 기억력, 어휘지식, 음운론 및 의미론적 과정 등의 인지 및 언어처리 과정이 모두 결합되어 표현되기 때문에 어떠한 하위요 소의 문제로든 이름대기의 어려움이 야기될 수 있다(Wolf \& Segal, 1992). 따라서 이름대기 처리과정에 영향을 미칠 수 있는 다양한 요 소들을 파악하는 것이 필요하다.

정서가 인지처리와 어휘처리에 미치는 영향을 조사한 연구들을 통해, 정서(emotion)가 어휘처리 과정에 영향을 미칠 수 있음이 밝 
혀지고 있다(Kim, 2019; Kousta, Vinson, \& Vigliocco, 2009; Vinson, Ponari, \& Vigliocco, 2014; Yap \& Seow, 2014). 정서는 일반적 으로 정서가(valence)와 각성(arousal)의 두 가지 관점으로 설명되 는데, '정서가'란 정서가 긍정적인가 부정적인가를 지칭하는 반면, '각성'은 특정 정서의 강도(strength)를 의미하는 말로, 안정과 흥분 의 차원으로 설명된다(Lang, Bradley, \& Cuthbert, 1997; Russell, 2003; Russell \& Barrett, 1999).

부정정서가 어휘처리에 미치는 영향을 설명하는 자동경계가설 (automatic vigilance hypothesis)에 의하면, 부정적인 정서자극은 다른 정서자극에 비해 주의편향(attention bias)을 가지고, 주의를 이탈(delayed disengagement of attention)시키는 것이 오래 걸린다. 따라서 부정범주의 어휘자극은 긴 처리 시간을 보이게 된다(Estes \& Adelman, 2008). Kuperman, Estes, Brysbaert 그리고 Warriner (2014)는 자동경계가설을 지지하며 부정범주와 긍정범주의 어휘 자극을 사용하여 어휘판단 과제를 실시한 결과, 긍정범주보다 부 정범주의 어휘에서 단어재인 속도가 더 느렸다고 보고하였다. 또한 자동경계가설과 일치하는 결과를 보이는 선행연구들은 정서 스트 룹 과제(emotional Stroop task)에서 긍정 및 중립범주 어휘보다 부 정범주 어휘에서 주의편향이 있었다고 보고하였다(Kahan \& Hely, 2008; McKenna \& Sharma, 1995; Pratto \& John, 1991). 그러나 Estes 와 Verges (2008)는 자동경계가설에 따른 부정정서의 영향이 과 제 유형에 따라 다를 수 있다고 보고하며 다음과 같은 실험결과를 제시하였다. 첫 번째 실험은 정서판단 과제(정서관련 과제)로, 피험 자들은 제시된 단어(예: 뱀)가 가진 정서(긍정 또는 부정)를 판단해 야 했다. 실험결과, 피험자들은 긍정범주보다 부정범주에서 더 빠 른 반응시간과 높은 정확도를 보인 것으로 나타났다. 두 번째 실험 은 어휘판단 과제(정서무관련 과제)로, 피험자들은 제시된 단어 (예: 뱀)가 단어인지 비단어인지 판단해야 했다. 실험결과 피험자들 은 긍정범주보다 부정범주에서 낮은 정반응률과 길어진 반응시간 을 보였다. 즉, 부정적인 정서와 관련된 자극이 어휘처리를 방해하 는 경우는, 과제가 정서와는 무관한 질문에 대답하기를 요구하는 과제(정서무관련 과제)에서만 확인 가능한 것으로 나타났다. 이름 대기 또는 어휘판단 과제와 같이 정서라는 요인을 직접적으로 물어 보지 않는 정서처리와 무관한 과제를 수행해야 할 경우, 피험자가 인지하지 못하지만 정서적인 요인이 단어재인에 개입하여, 부정정 서에 주의가 편향되어 어휘인출처리를 저하시키는 결과를 초래하 는 것으로 보고하였다.

몇몇 연구들은 정서무관련 과제에서, 부정정서뿐만 아니라 긍정 정서도 어휘처리를 억제할 수 있다고 제안하였다. Ihssen, Heim과 Keil (2007)은 어휘판단 과제에서, 정서 사진을 어휘판단 문제 사이
에 제시함으로 정서가 어휘판단 과제에 미치는 영향을 조사하였다. 실험결과, 중립범주 사진보다 정서범주(긍정, 부정) 사진이 제시되 었을 때 어휘판단 속도가 느린 것으로 나타났으며, 이는 실험에 사 용된 정서범주(긍정, 부정) 사진의 각성가가 중립범주 사진에 비에 높았기 때문에 나타난 결과일 수 있다고 제안하였다. Hinojosa, Méndez-Bértolo, Carretié 그리고 Pozo (2010)는 정서가 음운부호 화 과정(phonological encoding)에 미치는 영향을 Event-Related Potential (ERP) 성분(component)분석을 통해 살펴봄으로, 정서가 어휘인출(word production)에 부정적인 영향을 미칠 수 있음을 밝 혔다. 실험에서 살펴본 P400 (positive component)은 음운부호화 과정에서 관찰되는 ERP성분으로, 자극의 제시 후 300-400 ms 근 방에서 나타나는 양적(positive)방향의 정점으로 알려져 있다(Hauk, Rockstroh, \& Eulitz, 2001; Indefrey \& Levelt, 2004; Laganaro et al., 2009). 실험과제로는, 음운부호화 과제로 자소모니터링 과제(grapheme monitoring task)를 사용하였고, 정서자극으로 국제정서사 진체계 International Affective Picture System (IAPS; Lang, Bradley, \& Cuthbert, 2005) 사진을 사용하였다. 실험결과, 중립범주보다 긍정범주와 부정범주에서 반응시간이 유의하게 길었고, $\mathrm{P} 400$ 의 진 폭(amplitude)이 유의하게 큰 것으로 나타났다. 저자는 이러한 결 과에 대해, 정서자극에 편향된 주의가 어휘 산출 과정에서 음운적 자질(phonological properties)로의 접근을 방해한 결과라고 제안 하였다. 이러한 연구결과들은 정서가 범주(긍정, 부정, 중립)에 따 라 어휘처리에 미치는 영향이 다를 수 있으며 또한 과제 유형에 따 라서도 다르게 영향을 미칠 수 있다는 점을 시사한다.

정서가 어휘처리 과정에 미치는 영향은 연령에 따라서도 다를 수 있다. 노년층의 경우, 정상적인 노화의 과정으로 작업기억, 주의력, 억제와 같은 인지-언어 능력의 감퇴(Park, 2004)로 인해 정신 조작 을 수행하는 속도가 전반적으로 감소하고(Salthouse, 1996) 처리 자원을 요구하는 인지과제 수행에서 결함을 보일 수 있다고 보고된 다(Craik \& Byrd, 1982). 또한 노화에 따른 주의력 감퇴로 인해 주 어진 과제에 집중하고 구어 정보를 인출(retrieval)하는데 어려움을 보인다고 보고된다(Kim et al., 2013). 그러나 노년층이 정서 정보를 처리할 때에는 청년층과 연령에 따른 차이를 보이지 않는다는 연구 결과들이 있다(Kim \& Jin, 2016; Mikels, Larkin, Reuter-Lorenz, \& Carstensen, 2005; Samanez-Larkinet, Robertson, Mikels, Carstensen, \& Gotlib, 2009). 사회정서적 선택 이론(socioemotional selective theory)에 따르면, 노인의 경우 사회적 목표 중 정서적 안녕감 유지와 관련된 목표에 우선순위를 두도록 동기를 부여하는데(Mather \& Carstensen, 2005), 이는 부정적인 정서 경험을 줄이고, 긍정 적인 정서 경험을 최대화하기 위해 능동적으로 자신의 정서를 조절 
하는 결과로 나타난다. 따라서 노인들은 부정적인 정보보다 긍정적 인 정보에 주의가 편향되는 긍정성 효과(positivity effect)를 보인다 (Charles, Mather, \& Carstensen, 2003). 긍정성 효과는 주로 기억인 출 과제에서, 노년층이 중립 및 부정범주 어휘보다 긍정범주 어휘 를 많이 기억한다는 실험결과에 의해 지지되어왔다(Lee \& Kang, 2019; Nam \& Bang, 2018). 그러나 기억인출에서의 긍정편향은 비 교적 일관되지만(Reed, Chan, \& Mikels, 2014), 주의 단계에서는 노 년층이 긍정정서에 주의편향을 보인다는 결과와(Isaacowitz, Ton$\mathrm{er}, \mathrm{Goren}, \& \mathrm{Wilson}, 2008)$ 부정정서에 주의편향을 보인다는 결과 가(Thomas \& Hasher, 2006; Wood \& Kisley, 2006) 다수 혼재되어 나타나고 있어 정서가 노년층의 인지 능력에 미치는 영향은 인지영 역의 종류와 과제에 따라 다를 수 있다. 정서가 노년층의 어휘인출 (lexical retrieval)에 미치는 영향을 조사한 Blackett, Harnish, Lundine, Zezinka 그리고 Healy (2017)는 청년층과 노년층에게 정서범 주(긍정, 부정, 중립) 사진자극을 사용하여 대면이름대기 과제를 실 시하였다. 연구결과, 청년층과 노년층 모두, 중립범주보다 정서범주 (긍정, 부정)에서 유의하게 길어진 반응시간을 보였으나, 노년층이 청년층에 비해 더 길어진 반응시간을 보임으로 정서에 의한 간섭을 더 크게 받은 것으로 나타났다. 이러한 결과는 노년층의 노화에 의 한 주의자원의 감소와, 청년층에 비해 정서자극에 더 편향된 주의 를 보이는 것에 따른 결과로 해석된다.

이와 같이 정서가 어휘처리에 미치는 영향에 대한 연구가 활발히 이루어지고 있음에도 불구하고, 정서가 직접적인 어휘인출에 미치 는 영향을 조사한 국내연구는 부족한 실정이다. 따라서 본 연구에 서는 정서(긍정, 부정, 중립)자극사진을 사용하여 정상 노년층과 청 년층의 대면이름대기 과제 수행 능력을 살펴봄으로 정서와 어휘인 출과의 관련성을 더욱 분명하게 밝히고자 하였다. 연구 질문은 다 음과같다.

첫째, 시각적 자극의 정서가(긍정, 부정, 중립)에 따라 대면이름대 기 과제에서 집단(노년, 청년) 간 정반응률 차이가 유의한가?

둘째, 시각적 자극의 정서가(긍정, 부정, 중립)에 따라 대면이름 대기 과제에서 집단(노년, 청년) 간 반응시간 차이가 유의한가?

Table 1. Demographic information on participants

\begin{tabular}{|c|c|c|c|c|c|c|}
\hline & \multicolumn{2}{|c|}{ Gender } & \multicolumn{2}{|c|}{ Age (yr) } & \multicolumn{2}{|c|}{ Education (yr) } \\
\hline & Male & Female & Mean (SD) & Range & Mean (SD) & Range \\
\hline Old ( $N=30)$ & 10 & 20 & $66.68(3.4)$ & $60-73$ & $13.03(1.67)$ & $12-16$ \\
\hline Young ( $\mathrm{N}=30$ ) & 5 & 25 & $22.17(2.74)$ & $19-30$ & $13.07(1.43)$ & $12-16$ \\
\hline
\end{tabular}

$\mathrm{SD}=$ standard deviation

\section{연구방법}

\section{연구대상}

본 연구는 정상 노년층 30 명과 정상 청년층 30 명, 총 60 명을 대상 으로 진행되었다. 청년층은 만 19-39세, 노년층은 만 60-79세의 연 령범위를 기준으로 집단을 구분하였다. 본 연구의 모든 절차와 방 법은 이화여자대학교 생명윤리위원회의 기준을 따랐으며, 승인을 받은 후 절차대로 진행하였다(ewha-202009-0015-01). 청년층과 노 년층의 공통적인 선별 기준은 다음과 같다. 두 집단은 (1) 모국어로 한국어를 사용하고, (2) 교육연수가 9년 이상이며, (3) 서울 및 인천, 경기도, 충청 지역에 거주하고, (4) 건강선별설문지(Christensen, Multhaup, Nordstrom, \& Voss, 1991)에 근거하여 언어 및 인지발 달 문제 및 신경학적, 정신적 병력과 두뇌손상 병력이 없고, (5) 자가 보고(self-report)를 통한 시력 설문, 청력 설문에서 이상이 없으며, (6) 한국판 간이정신상태 검사(Korean-Mini Mental State Examination, K-MMSE; Kang, Na, \& Hahn, 1997) 결과가 연령 및 교육연 수에 따른 정상범위(16\%ile 이상)에 해당하는 자(Kang, 2006)로 선 정하였다.

노년층에게는 추가로 서울언어학습검사(Seoul Verbal Learning Test, SVLT; Kang, Jang, \& Na, 2012)를 실시하여, 점수가 연령 및 교육연수에 따라 $16 \%$ ile 이상의 정상범주에 해당하는 자를 선별 하였다. 또한 단축형 노인 우울 척도(Korean version of the Short form of Geriatric Depression Scale, SGDS-K; Jo et al., 1999)를 실 시하여 점수가 8점 미만에 해당하는 자를 선별하였다. 본 연구에 참여한 집단별 대상자의 연령, 교육연수 정보는 Table 1에 제시하 였으며 선별검사 점수는 Table 2에 제시하였다. 집단(노년, 청년) 간 교육연수에서 유의한 차이가 있는지 알아보기 위해 독립표본 $t$-검 정(independent samples $t$-test)을 실시하였으며, 집단 간 교육연수 평균은 통계적으로 유의하지 않는 것으로 나타났다 $\left(t_{58}=-.083\right.$, $p>$.05).

Table 2. Descriptive data from neuropsychological tests

\begin{tabular}{lcccc}
\hline & K-MMSE & SVLT-IM & SVLT-D & SGDS \\
\hline Old $(\mathrm{N}=30)$ & $28.6(1.25)$ & $23.73(3.87)$ & $8.13(2.29)$ & $1.27(1.86)$ \\
Young $(\mathrm{N}=30)$ & $29.73(.52)$ & & & \\
\hline
\end{tabular}

Values are presented as mean (SD).

K-MMSE = Korean version of Mini State Examination (Kang, Na, \& Hahn, 1997); SVLT-IM = Seoul Verbal Learning Test-Immediate recall (Kang, Jang, \& Na, 2012); SVLT-D=Seoul Verbal Learning Test-Delayed recall (Kang, Jang, \& Na, 2012); SGDS= Korean version of the Short form of Geriatric Depression Scale (Jo et al., 1999). 


\section{연구과제}

사진자극

본 연구에서는 대면이름대기 과제에 사용될 정서자극으로 국제 정서사진체계인 International Affective Picture System (IAPS; Lang et al., 2005)를 이용하였다. 이 체계는 Florida 대학 정서 연구 소에서 표준화한 국제정서그림체계(Lang et al., 2005)로 약 1,000 장의 동일한 해상도 $(1,024 \times 768)$ 의 컬러사진으로 구성되어 있다. IAPS 사진들은 지난 십여 년간 미국인을 대상으로 반복적으로 평 가되었으며, 각 사진마다 긍정과 부정으로 구분되는 '정서가'와 안 정과 흥분으로 구분되는 '각성'에 대한 표준화된 평가 값을 제시하 고 있다. 이러한 IAPS 자극은 다양한 정서처리 연구에 정서자극으 로 흔히 사용되고 있다.

IAPS 자극은 각 사진의 정서가와 각성가에 대한 표준화 자료를 이미 제공하고 있지만, 본 실험에는 한국과 미국의 문화 차이를 고 려하여 Park과 Park (2009)의 한국인 대학생 832명을 대상으로 평 정한 정서가와 각성가를 사용하였다. 자극에 대한 정서가와 각성 가 평정은 9점 척도를 통하여 이루어졌으며, 정서가와 각성가 모두 최저점은 1점, 최고점은 9점이다. 정서자극의 정서범주 분류는, Park 과 Park (2009)의 기준을 참고하여 긍정정서 자극으로 정서가가 5.5점 초과인 자극을 선정하였고, 4.5-5.5점에 해당하는 자극을 중 립자극으로, 마지막으로 4.5 점 미만의 자극은 부정자극으로 분류 하였다.

\section{단어자극 및 사진 선정 절차}

이름대기에 영향을 미칠 수 있는 변수로는 단어빈도, 단어길이, 시각적 복잡성(visual complexity), 그리고 이름일치도(namimg agreement) 등이 있다(Barry, Morrison, \& Ellis, 1997; Griffin \& Bock, 1998; Huttenlocher \& Kubicek, 1983; Vitkovitch \& Tyrrell, 1995). 따라서 본 연구에서는 IAPS 사진자극을 대상으로 한국어의 단어빈도, 단어길이, 시각적 복잡성, 이름일치도, 그리고 조음 복잡 성에서 정서가(긍정, 부정, 중립) 간 통계적으로 유의하지 않도록 하 였으며 통제 절차는 다음과 같다.

\section{단어빈도}

국립국어연구원의 현대 국어 사용 빈도 조사 2 (2005)를 참고하 여 목표 어휘의 단어빈도를 정의하였다. 선정된 목표어휘의 단어빈 도 $(\mathrm{M}=120.85)$ 는 정서범주(긍정, 부정, 중립) 간 통계적으로 유의 한 차이가 없었다 $\left(F_{(2,36)}=.053, p=.948\right)$.

\section{단어길이}

선정된 목표어휘의 단어 음절 수( $\mathrm{M}=2.03)$ 는 정서범주(긍정, 부정, 중립) 간 통계적으로 유의한 차이가 없었다 $\left(F_{(2,36)}=.2 .688, p=.082\right)$

\section{시각적복잡성}

$\operatorname{Kim}$ (2012)을 참고하여 20명의 청년에게 Google 드라이브 설문 조사 링크를 전달하여, 목표 IAPS 사진자극의 시각적 복잡성에 대 해 5 점 척도로 평가하게 하였다. 사진의 전경과 배경이 잘 분리되며, 단순하여 사진의 내용을 확연히 알 수 있는 경우 1 점에 가깝게, 전 경과 배경이 잘 분리되지 않아 사진을 알아보기 어렵고, 복잡해 보 이는 경우 5 점에 가깝게 평가하도록 하였다 $(1=$ 매우 단순하다, $2=$ 조금 단순하다, $3=$ 보통이다, $4=$ 조금 복잡하다, $5=$ 매우 복잡하 다). 선정된 목표어휘의 시각적 복잡성 $(\mathrm{M}=2.1)$ 은 정서범주(긍정, 부정, 중립 $)$ 간 통계적으로 유의한 차이가 없었다 $\left(F_{(2,22.357)}=1.362\right.$, $p=.277)$.

이름일치도

Choi (2008), Snodgrass와 Vanderwart (1980)의 방법을 참고하 여 35명의 청년에게 Google 드라이브 설문조사 링크를 전달하여, 목표 사진자극에 대한 이름일치도를 조사하였다. 설문 참가자는 설문지의 사진자극을 본 후, 가장 먼저 떠오르는 단어의 이름을 적 었다. 설문결과를 바탕으로, 가장 많은 사람들이 동의한 이름의 백 분율(\%)을 산출하고 자극 사진의 이름으로 정하였으며 평정결과 $70 \%$ 미만의 이름일치도를 보이는 자극사진은 제외하였다. 이후 위 와 동일한 방법으로 청년 20명을 대상으로 Google 드라이브의 설 문지를 이용하여, 이름일치도 2 차 평정을 진행하였다. 선정된 목표 어휘의 이름일치도 $(\mathrm{M}=91.88)$ 는 정서범주(긍정, 부정, 중립) 간 통 계적으로 유의한 차이가 없었으며 $\left(F_{(2,36)}=.179, p=.836\right)$, 각 범주별 이름일치도의 평균은 $90 \%$ 이상이었다.

\section{조음 복잡성}

Lee, Han과 Sim (2004)의 연구에서 사용된 한국어 조음 복잡성 지표를 기준으로 조음 복잡성을 계산하였다. 선정된 목표어휘의 조음 복잡성 점수 $(\mathrm{M}=3)$ 는 정서범주(긍정, 부정, 중립) 간 통계적 으로 유의한 차이가 없었다 $\left(F_{(2,36)}=.286, p=.753\right)$.

최종적으로 각 정서범주(긍정, 부정, 중립)에서 13 개의 사진이 선 별되어 총 39 개의 IAPS 사진자극을 대면이름대기 과제의 사진자극 으로 사용하였다. 선정된 자극의 정서범주(긍정, 부정, 중립) 간 정서 가의 차이가 통계적으로 유의하였다 $\left(F_{(2,19.603)}=81.230, p<.0001\right)$. 이에 따른 Dunnett 사후검정 결과, 긍정, 부정, 중립 세 범주에 따른 
정서가 차이가 유의하였으며 $(p<.0001)$, ‘부정<중립<긍정' 순으 로 정서가가 높았다. 각성가의 차이 또한 통계적으로 유의하였다 $\left(F_{(2,36)}=40.249, p<.0001\right)$. 이에 따른 Bonferroni 사후검정 결과 긍 정범주와 중립범주의 각성가 차이는 유의하지 않았고 $(p=.1)$, 긍정 범주와 중립범주의 각성가는 부정범주의 각성가보다 통계적으로 유의하게 낮았다 $(p<.0001)$. 사진자극의 예는 Figure 1에 제시하였 으며, IAPS 자극의 저작권 제한으로 인해 본 실험에서 사용된 IAPS 자극과 유사한 사진자극으로 제시하였다. 정서범주 별 자극사진 목 록은 Appendix 1에 제시하였다.

본 실험에 사용된 실험도구는 실험프로그램 E-Prime (ver2.1)에 서 제작되어 개인용 노트북 S14 S430FA-EB212에서 제어되었다. 실 험에 사용된 목표 사진자극은 14 인치 노트북에서 E-Prime 프로그 램의 흰색 화면 정 중앙에 하나씩 제시되었다. 순서효과를 배제하기 위해 정서범주(긍정, 부정, 중립)의 제시 순서를 교차균형화(Count balance)하여 총 6개의 세트를 제작하였고, 범주 내 목표자극은 세 트 별로 임의의(random) 순서를 만들어 제시하였다. 피험자들은 교차균형화한 6가지 세트(version) 중 한 가지 세트로 실험에 임하 게 되었다.

\section{연구절차}

실험절차는 다음과 같다. 실험은 소음이 없는 조용한 장소에서 개별적으로 실시되었다. 피험자는 노트북 화면에 제시된 사진을 보 고 사진의 이름을 가능한 한 빨리, 그리고 정확하게 말해야 한다. 한 사진의 이름대기를 끝내면 피험자는 키보드의 오른쪽 화살표를 통해 화면을 넘기게 되고, 곧이어 나타나는 사진의 이름을 다시 빠 르고 정확하게 말해야 한다. 검사자는 피험자에게 본 실험을 시작 하기 전 "이제부터 화면에 사진이 하나씩 나올 거예요. 사진의 이름 을 가능한 한 빨리, 그리고 정확하게 말씀해주세요.”라고 지시하였
다. 또한 실험절차를 충분히 이해할 수 있도록 연습문항을 시행하 는 과정을 거친 후 본 실험을 실시하였다. 한 정서범주의 이름대기 가 끝날 때마다 노인기억장애검사(Elderly Memory disorder Scale; Choi, 2007)의 시공간적 작업기억 용량을 측정하는 과제인 시공간 폭 검사를 실시하였다. 검사 항목은 '바로 따라 하기'와 '거꾸로 따 라 하기' 로 구성되어 있으며, 검사 진행은 검사자가 시공간폭 검사 판의 블록을 특정한 순서로 가리키는 것을 피험자가 기억하고 따 라 하는 방식으로 이루어진다. 한 정서범주의 이름대기가 끝날 때 마다 시공간폭 검사를 실시하여 앞서 본 사진자극의 정서가 남아 있는 것과 반복되는 이름대기 작업으로 인한 피로를 방지하였다. 실험 과정은 모두 E-Prime 프로그램으로 노트북에 탑재된 음성 녹음기를 통해 녹음하였으며, 실험 소요시간은 노년층의 경우 약 $15-20$ 분, 청년층의 경우 약 10 분이었다.

\section{자료분석}

정반응률(Accuracy)

본 연구에서는 반응 정확도를 기록하기 위해, Snodgrass와 Vanderwart (1980)의 연구와 Choi (2008)의 연구에서의 '온건한 기준' 을 참고하였으며, 각 범주별로 정반응한 문항 수를 세어서 전체 문 항으로 나눈 후 100 을 곱하여 정반응률을 산출하였다.

반응 정확도 $(\%)=($ 정반응한 문항 수 $/$ 전체 문항 수 $) \times 100$

\section{반응시간(Response Time)}

본 과제에 사용된 대면이름대기 과제에서 대상자의 발화는 EPrime을 이용하여 녹음되었다. E-Prime에 의해 사진이 제시되는 순간부터 사진의 이름을 명명한 후 다음으로 넘어가기 위해 키보 드를 누르기까지의 모든 과정은 노트북에 탑재된 마이크를 통하여 녹음되어 하나의 개별 파일로 저장되었다. 반응시간 분석은 모든

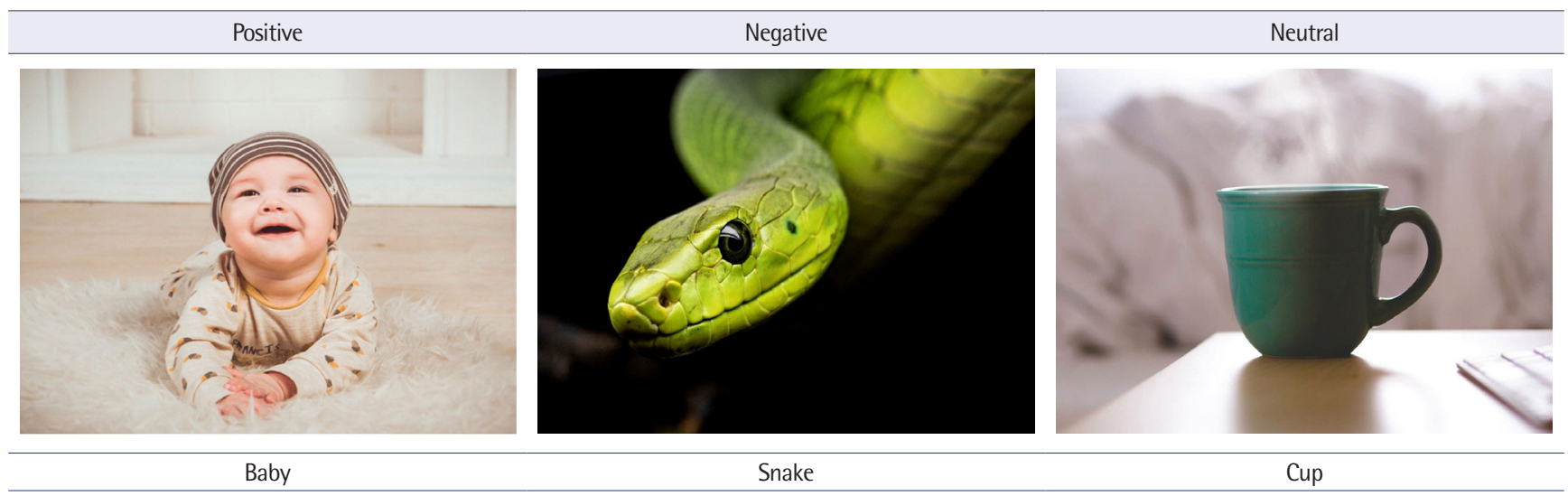

Figure 1. Examples of stimuli. 
녹음을 마친 후, 저장된 음성을 음향분석 프로그램인 Praat을 사 용하여 소리파형(wave form)으로 불러와 피험자에게 목표자극이 화면에 제시된 순간(0초로 맞춰져 있음)부터 피험자가 구어적으로 반응할 때까지의 시간을 $\mathrm{ms}(1 / 1,000$ 초 $)$ 로 측정하였다.

인지 과제의 반응시간 분석과 관련된 선행연구(Glickman, Gray, \& Morales, 2005)를 참고하여 정반응 외의 오반응에 대한 반응시간 을 포함하여 분석할 경우, 과제 해결을 위한 처리과정의 속도뿐만 아니라 관련 없는 처리과정의 소요시간도 포함될 수 있다는 근거에 따라 반응시간 분석에는 정반응한 단어의 시간만 분석하였다.

\section{자료의 통계적 처리}

본 실험결과는 SPSS 25.0 for Windows 프로그램을 사용하여 통 계 처리하였다. 시각적 자극의 정서가에 따른 대면이름대기 과제에 서 집단 간 정반응률과 반응시간의 차이가 유의한지 알아보기 위 해 집단(노년, 청년) $\times$ 정서가(긍정, 부정, 중립)의 이원혼합분산분 석(two-way mixed ANOVA)을 실시하여 분석하였다. 연령으로 구 분된 집단은 피험자 간 요인(between subject factors)으로, 정서가 에 따라 구분된 요인(긍정, 부정, 중립)은 피험자 내 요인(within subject factors)으로 하였다.

첫 번째 연구질문과 두 번째 연구질문 모두, 이원혼합분산분석 실시 후 주효과가 유의할 경우 Bonferroni를 이용하여 사후검정을 실시하였다. 또한 통계 분석에서 구형성 가정을 만족하지 않은 경 우 Greenhouse-Geisser correction한 $p$-value를 제시하였다.

\section{연구결과}

\section{정반응률}

시각적 자극의 정서가에 따른 대면이름대기 과제에서 집단 간 정

Table 3. Descriptive statistics of accuracy (\%)

\begin{tabular}{llll}
\hline \multirow{2}{*}{ Emotional valence } & Group & \multicolumn{2}{c}{ Accuracy (\%) } \\
\cline { 3 - 4 } Positive & Old & 92.05 & SD \\
& Young & 96.67 & 9.58 \\
& Mean & 94.36 & 4.82 \\
Negative & Old & 87.69 & 9.67 \\
& Young & 98.72 & 3.55 \\
& Mean & 93.21 & 9.08 \\
Neutral & Old & 98.46 & 3.13 \\
& Young & 99.49 & 1.95 \\
& Mean & 98.97 & 2.64 \\
\hline
\end{tabular}

$\mathrm{SD}=$ standard deviation
반응률의 차이가 있는지 확인하기 위해 개체 간 조건으로 집단(노 년, 청년)을 두고 개체 내 조건으로 정서가(긍정, 부정, 중립)를 설정 하여 이원혼합분산분석(two-way mixed ANOVA)을 실시하였다. 시각적 자극의 정서가에 따른 정반응률에서 집단 간 평균 및 표준 편차는 Table 3, Figure 2에 제시하였으며 분산분석 결과는 Table 4 에 제시하였다.

시각적 자극의 정서가에 따른 대면이름대기 과제에서 집단에 대 한 주효과가 통계적으로 유의했다 $\left(F_{(1,58)}=25.394, p<.0001\right)$. 즉 노 년층의 이름대기 과제에서의 평균 정반응률 $(\mathrm{M}=92.74)$ 이 청년층 의 이름대기 과제에서의 평균 정반응률 $(\mathrm{M}=98.29)$ 보다 낮았다. 정 서가(긍정, 부정, 중립)에 대한 주효과 또한 통계적으로 유의했다 $\left(F_{(1.758,101.949)}=18.043, p<.0001\right)$. 이에 Bonferroni 사후검정을 실시 한 결과, 긍정범주 $(\mathrm{M}=94.36, \mathrm{SD}=7.87)$ 와 중립범주 $(\mathrm{M}=98.97$, $\mathrm{SD}=2.64)$ 간 차이가 통계적으로 유의하였으며 $(p<.0001)$, 부정범 주와 $(\mathrm{M}=93.21, \mathrm{SD}=9.08)$ 중립범주 간 차이가 통계적으로 유의하 였다 $(p<.0001)$. 그러나 긍정범주와부정범주 간 차이는 통계적으로 유의하지 않았다 $(p=1)$. 마지막으로 시각적 자극의 정서가에 따른 집단 간 이차상호작용이 통계적으로 유의하였다 $\left(F_{(1.758,101.949)}=12.421\right.$, $p<.0001)$. 이에 따른 사후검정을 LMATRIX와 MMATRIX 명령 문을 사용하여 실시하였다. 그 결과, 부정범주에서의 집단 간차이가 긍정범주에서 집단 간 차이보다 유의하게 차이가 컸으며 $(p<.01)$,

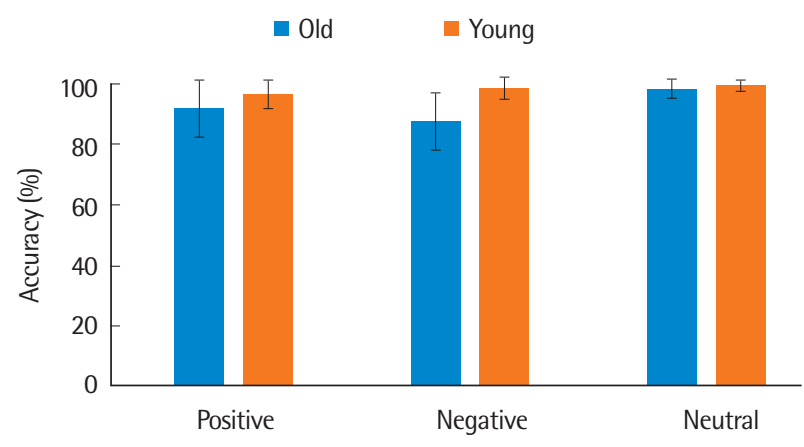

Figure 2. Accuracy (\%) for each condition in young and elderly groups.

Table 4. The result of two-way mixed ANOVA

\begin{tabular}{lrcrr}
\hline & $\begin{array}{c}\text { Sum of } \\
\text { square }\end{array}$ & $\begin{array}{c}\text { Degree of } \\
\text { freedom }\end{array}$ & $\begin{array}{c}\text { Mean } \\
\text { square }\end{array}$ & $F$ \\
\hline Group & $1,388.889$ & 1 & $1,388.889$ & $25.394^{* * *}$ \\
Error & $3,172.255$ & \multicolumn{1}{c}{58} & 54.694 & \\
Valence & $1,118.343$ & 1.758 & 636.238 & $18.043^{* * *}$ \\
Valence $\times$ Group & 769.888 & 1.758 & 437.998 & $12.421^{* * *}$ \\
Error & $3,595.003$ & 101.949 & 35.263 & \\
\hline
\end{tabular}

***p $p .001$. 
Table 5. Descriptive statistics of response time (ms)

\begin{tabular}{llrc}
\hline \multirow{2}{*}{ Emotional valence } & Group & \multicolumn{2}{c}{ Response time } \\
\cline { 3 - 4 } Positive & & Mean & SD \\
& Old & $1,298.66$ & 265.31 \\
& Young & 914.61 & 159.72 \\
Negative & Mean & $1,106.64$ & 290.92 \\
& Old & $1,518.80$ & 451.50 \\
& Young & $1,031.64$ & 239.95 \\
Neutral & Mean & $1,275.22$ & 434.55 \\
& Old & $1,067.75$ & 224.28 \\
& Young & 811.74 & 129.98 \\
& Mean & 939.74 & 222.92 \\
\hline
\end{tabular}

$\mathrm{SD}=$ standard deviation

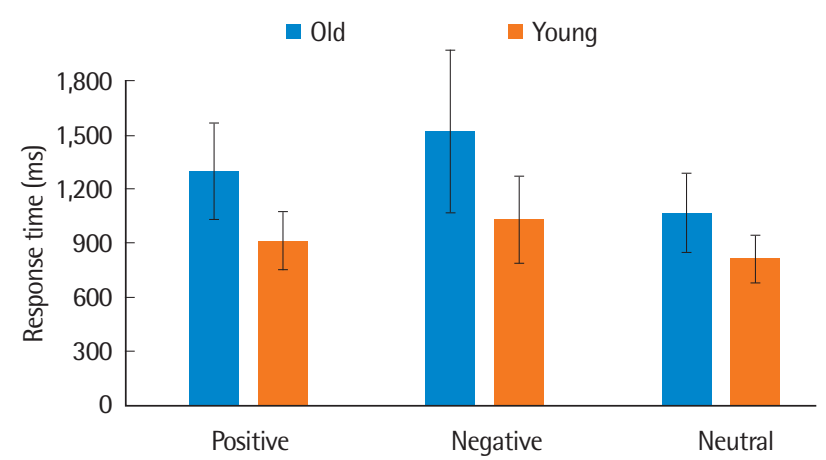

Figure 3. Response time (ms) for each condition in young and elderly groups.

부정범주에서 집단 간 차이가 중립 범주에서 집단 간 차이보다 유 의하게 큰 차이가 있는 것으로 나타났다 $(p<.0001)$. 그러나 긍정범 주에서 집단 간 차이는 중립범주에서의 집단 간 차이와 유의한 차 이가 없었다 $(p=.059)$. 즉 유의한 이차상호작용은 부정범주에서 노 년층의 이름대기 정반응률이 청년층에 비해 낮은 것에 기인한다.

\section{반응시간}

시각적 자극의 정서가에 따른 대면이름대기 과제에서 집단 간 반 응시간의 차이가 있는지 확인하기 위해 개체 간 조건으로 집단(노 년, 청년)을 두고 개체 내 조건을 정서가(긍정, 부정, 중립)로 하고 이원혼합분산분석(two-way mixed ANOVA)을 실시하였다. 시각 적 자극의 정서가에 따른 반응시간에서 집단 별 평균 및 표준편차 는 Table 5, Figure 3에 제시하였으며 분산분석 결과는 Table 6에 제 시하였다.

시각적 자극의 정서가에 따른 대면이름대기 과제에서 집단에 대 한 주효과가 통계적으로 유의했다 $\left(F_{(1,58)}=48.051, p<.0001\right)$. 즉 노년 층의 이름대기 과제에서의 평균 반응시간 $(\mathrm{M}=1,295.07)$ 이 청년층 의 평균 반응시간 $(\mathrm{M}=919.33)$ 보다 유의하게 길었다. 정서가(긍정,
Table 6. The result of two-way mixed ANOVA

\begin{tabular}{lrccc}
\hline & $\begin{array}{c}\text { Sum of } \\
\text { square }\end{array}$ & $\begin{array}{c}\text { Degree of } \\
\text { freedom }\end{array}$ & $\begin{array}{c}\text { Mean } \\
\text { square }\end{array}$ & $F$ \\
\hline Group & $6,353,129.02$ & 1 & $6,353,129.02$ & $48.051^{* * *}$ \\
Error & $7,668,524.71$ & 58 & $132,215.943$ & \\
Valence & $3,376,475.42$ & 1.664 & $2,029,550.47$ & $42.181^{* * *}$ \\
Valence $\times$ Group & $402,277.17$ & 1.664 & $241,802.98$ & $5.026^{*}$ \\
Error & $4,642,728.43$ & 96.492 & $48,115.12$ & \\
\hline
\end{tabular}

${ }^{*} p<.05,{ }^{* * *} p<.001$.

부정, 중립)에 대한 주효과 또한 통계적으로 유의했다 $\left(F_{(1.664,96.492)}=\right.$ $42.181, p<.0001)$. 이에 Bonferroni 사후분석 실시 결과, 긍정범주 $(\mathrm{M}=1,106.64, \mathrm{SD}=290.92)$, 부정범주 $(\mathrm{M}=1,275.22, \mathrm{SD}=434.55)$, 중립범주 $(\mathrm{M}=939.74, \mathrm{SD}=222.92)$, 즉 세 정서 범주 모두에서 반응 시간 차이가 유의한 것으로 나타났다 $(p<.0001)$. 다음으로 시각적 자극의 정서가에 따른 집단 간 이차상호작용이 통계적으로 유의하 였다 $\left(F_{(1.664,96.492)}=5.026, p<.05\right)$. 이에 따른 사후검정을 LMATRIX 와 MMATRIX 명령문을 사용하여 실시하였다. 그 결과, 긍정범주 에서 집단 간 반응시간의 차이와 부정범주에서 집단 간 반응시간 의 차이는 유의하지 않았다 $(p=.17)$. 그러나 긍정범주에서 집단 간 반응시간의 차이와 부정범주에서의 집단 간 반응시간의 차이는 중 립범주에서의 집단 간 반응시간의 차이와 유의한 차이가 있는 것 으로 나타났다 $(p<.05)$. 즉 유의한 이차상호작용은 긍정범주와 부 정범주에서 노년층의 반응시간이 청년층에 비해 길어진 것에 기인 한다.

\section{논의 및 결론}

본 연구는 노년층과 청년층을 대상으로 정서가(긍정, 부정, 중립) 가 대면이름대기 능력에 미치는 영향을 확인하고자 하였다. 따라서 정서가에 따른 청년 및 노년 집단 간 대면이름대기 과제에서의 (1) 정반응률, (2) 반응시간을 알아보았다. 본 연구의 결과를 정반응률 과 반응시간으로 나누어 살펴본 결과는 아래와 같다.

시각적 자극의 정서가에 따른 대면이름대기 과제에서 두 집단 간 정반응률 차이가 유의한지 살펴보았다. 그 결과, 두 집단 간 정반응 률 차이가 유의했으며, 노년층이 청년층보다 낮은 정반응률을 보였 다. 즉 노년층이 청년층보다 유의하게 낮은 이름대기 능력을 보이는 것으로 나타났으며, 이는 노화에 따른 노년층의 이름대기 능력의 수행력 저하를 보고한 다수의 선행연구들과 일치하는 결과이다 (Barresi et al., 2000; Feyereisen, 1997; Kim et al., 2013; Mortensen et al., 2006; Nicholas et al., 1985; Ramsay et al., 1999; Schmitter- 
Edgecombe et al., 2000).

또한 시각적 자극의 정서가에 따라 정반응률의 차이가 유의한지 살펴본 결과, 정서가에 따른 정반응률 차이가 유의했다. 청년층과 노년층 모두 중립범주에 비해 긍정범주와 부정범주에서 낮은 정반 응률을 보였고 긍정범주와 부정범주에서의 정반응률 차이는 유의 하지 않았다. 즉, 청년층과 노년층 모두 중립범주보다 정서범주(긍 정, 부정)에서 낮은 정반응률을 보였는데, 이는 정서가 어휘처리에 영향을 미칠 수 있다는 선행연구들과 흐름을 같이하고(Kim, 2019; Kousta et al., 2009; Vinson et al., 2014;), 또한 정서가 어휘인출 과정 에 부정적인 영향을 미칠 수 있다는 선행연구를 지지하는 결과이 다(Blackett et al., 2017; Hinojosa et al., 2010). 이러한 결과는 정서 자극에 대한 주의의 편향(Cuthbert, Schupp, Bradley, Birbaumer, \& Lang, 2000; Dillon, Cooper, Grent, Woldorff, \& LaBar, 2006)으 로 정서적 자극에 주의자원이 배분되고, 이에 따른 결과로 어휘인 출 과정이 방해를 받아 나타난 결과일 수 있다(Blackett et al., 2017; Hinojosa et al., 2010).

마지막으로 집단과 정서가에 대한 이차상호작용이 통계적으로 유의하였다. 사후분석 결과, 유의한 이차상호작용은 부정범주에서 노년층의 수행력이 저하되는 것에 기인한 것으로 나타났다. 이러한 결과는 부정정서에 따른 주의편향의 영향(Estes \& Verges, 2008)을 청년층보다 노년층이 더 크게 받은 것에 의한 결과로 해석된다. 노 인은 노화에 따른 작업기억, 주의력 등과 같은 인지 능력의 저하로 처리 자원(processing resources)의 양이 감소함에 따라 인지과제 수행에서 결함을 보인다고 보고된다(Craik \& Byrd, 1982). 또한, 내 외적 자극에 산만해지지 않고 일정한 자극에 집중할 수 있는 능력 인 주의력 감퇴가 보고된다. 즉, 부정범주 자극에 편향된 주의가 어 휘의 처리를 방해하였고, 그 영향이 인지처리 자원 및 주의력 감퇴 를 보이는 노년층에게 더 크게 나타난 결과로 해석된다.

시각적 자극의 정서가에 따른 대면이름대기 과제에서 두 집단 간 반응시간의 차이가 유의한지 살펴보았다. 그 결과 노년층이 청년층 보다 유의하게 긴 반응시간을 보였다. 이는 노화에 따른 이름대기 능력의 저하로, 청년층에 비해 노년층의 이름대기 반응시간이 길다 는 선행 연구들과 일치하는 결과이다(Barresi et al., 2000; Feyereisen, 1997; Kim et al., 2013; Mortensen et al., 2006; Nicholas et al., 1985; Ramsay et al., 1999; Ratcliff et al., 2004; Schmitter-Edgecombe et al., 2000).

시각적 자극의 정서가에 따른 반응시간 또한 통계적으로 유의한 차이가 있었다. 세 정서범주 모두에서 반응시간의 차이가 유의하였 으며, 중립<긍정<부정범주의 순서로 길어진 반응시간을 보였다. 청년층과 노년층 모두 중립범주에 비해 정서범주(긍정, 부정)에서
반응시간이 긴 것으로 나타났는데, 이러한 결과는 정서가 어휘처리 를 방해할 수 있다고 보고한 선행연구 결과와 흐름을 같이하며(Estes \& Verges, 2008; Ihssen et al., 2007), 정서가 어휘인출 과정을 방 해하여 긴 반응시간을 초래할 수 있다는 선행연구와 일치한다 (Blackett et al., 2017, Hinojosa et al., 2010), 이와 같은 결과는 정서 무관련 과제인 대면이름대기 과제에서 정서 정보에 편향된 주의가 어휘처리를 방해하여 초래한 결과로 해석될 수 있다(Hinojosa et al., 2010; Blackett et al., 2017).

특히, 청년층과 노년층 모두 부정범주의 자극 처리에서 가장 긴 반응시간을 보인 것으로 나타났다. 부정범주 자극의 각성가가 긍정 및 중립자극의 각성가보다 높았던 것을 고려할 때, 이러한 결과는 어휘처리가 각성가가 높은 정서자극에 의해 영향을 받을 수 있다 는 선행 연구(Ihssen et al., 2007)와 일치하는 결과이다. 또한 부정 정서 자극에 대한 주의편향으로 인해 부정범주의 어휘는 긍정범주 의 어휘보다 긴 처리시간을 보일 수 있다는 자동경계가설(Estes \& Adelman, 2008)과 일치하는 결과이다. 즉, 정서 정보에 편향된 주 의로 인해 중립범주보다 정서범주(긍정, 부정)에서 더 긴 반응시간 을 보이며, 긍정범주에 비해 부정범주에서 유의하게 길어진 반응시 간은 자극의 정서가 및 각성가 차이에 따른 결과일 수 있다.

마지막으로 시각적 자극의 정서가에 따른 집단 간 이차상호작용 이 통계적으로 유의하였다. 이차상호작용에 대한 사후분석 결과, 긍정범주와 부정범주에서 노년층의 반응시간이 청년층에 비해 길 어진 것에 기인한 결과로 나타났다. 이러한 결과는, 이름대기 과제 에서 청년층보다 노년층이 정서자극에 더 큰 방해 또는 간섭을 받 았다는 것을 시사하며, 선행연구 Blackett 등(2017)과 일치하는 결 과이다. 중립범주에 비해 정서범주(긍정, 부정)에서 노년층이 청년 층에 비해 더 길어진 반응시간을 보이는 것은 노년층의 처리 자원 감소(Craik \& Byrd, 1982)와주의력 감퇴로 인한 결과일 수 있다. 또 는 정서자극에 대한 노년층의 증가된 주의선호(attentional preference)에 따른 주의편향(attention bias)으로 인해 나타난 결과일 수 있다. 노년층이 긍정정서에 증가된 주의선호를 보인다는 선행연구 들이 있다(Charles et al., 2003; Mather \& Carstensen, 2005). 또한 노년층은 사망에 대한 불안감이 커짐에 따라 부정적인 자극에 대 한 증가된 주의선호를 보일 수 있다(Fox \& Knight, 2005). 따라서 청년층에 비해 노년층이 정서 정보 자극에 대한 선호도가 높아 정 서자극에 편향된 주의가 어휘인출을 방해했을 가능성이 있다(Blackett et al., 2017).

결론적으로 본 연구는 정서가 청년층과 노년층의 대면이름대기 에 영향을 미칠 수 있다는 것을 밝혔다. 청년층과 노년층 모두 중립 범주보다 정서범주(긍정, 부정)에서 낮은 정반응률과 길어진 반응 
시간을 보여, 정서자극이 이름대기 수행을 방해하는 것으로 나타 났다. 특히 주목할 만한 점은, 정서자극에 의한 방해가 청년층보다 노년층에게 더 큰 영향을 미쳤다는 것이다. 이는 노년층이 노화로 인한 처리 자원의 감소 및 주의력 감퇴로 인해 정서에 의한 간섭의 영향을 더 크게 받은 결과일 수 있다. 또한 정서자극에 대한 노년층 의 증가된 주의편향에 의한 결과일 수 있다.

본 연구결과는 향후 노년층의 이름대기 중재를 위한 프로그램 및 어휘 목록 개발에 도움을 줄 수 있다는 점에 임상적 의의가 있 다. 또한 국내의 정서와 어휘산출의 관련성에 대한 제한적인 연구 에 기초적 자료를 제공하는데 또 다른 의의가 있다. 연구의 제한점 및 후속연구를 위한 제안은 다음과 같다. 첫째, 본 연구에서는 청년 층과 노년층의 성별통제가 이루어지지 않아 성별에 따른 영향을 배 제하지 못하였다. 따라서 향후 연구에서는 성별에 따른 정서적 특 성에 대한 기초 자료를 확보할 필요가 있다. 둘째, 본 연구에서는 정 서자극의 단어빈도, 단어길이, 시각적 복잡성, 그리고 이름일치도 를 통제하여, 정서가 이름대기 능력에 미치는 영향을 살펴보고자 하였다. 향후 연구에서는 개인의 의미론적 언어 능력(예: 생성이름 대기 능력 등)을 추가로 확인하여 정서가 이름대기에 미치는 영향 을 살펴본다면, 정서와 언어의 관련성을 더욱 확실히 할 수 있을 것 으로 생각된다. 셋째, 본 연구는 정상 청년층 및 노년층만을 대상으 로 실시되었기 때문에, 향후 대상자 범주를 경도인지장애군(mild cognitive impairment) 또는 치매 환자 등으로 확대하여 정서가 이 름대기에 미치는 영향을 살펴볼 것을 제안한다.

\section{REFERENCES}

Barresi, B. A., Nicholas, M., Connor, L. T., Obler, L. K., \& Albert, M. L. (2000). Semantic degradation and lexical access in age-related naming failures. Aging, Neuropsychology, and Cognition, 7(3), 169-178.

Barry, C., Morrison, C. M., \& Ellis, A. W. (1997). Naming the Snodgrass and Vanderwart pictures: effects of age of acquisition, frequency, and name agreement. The Quarterly Journal of Experimental Psychology: Section A, 50(3), 560-585.

Burda, A. (2011). Communication and swallowing changes in healthy aging adults. Sudbury, MA: Jones and Bartlett Learning.

Blackett, D. S., Harnish, S. M., Lundine, J. P., Zezinka, A., \& Healy, E. W. (2017). The effect of stimulus valence on lexical retrieval in younger and older adults. Journal of Speech, Language, and Hearing Research, 60(7), 2081-2089.

Brown, R., \& McNeill, D. (1966). The "tip of the tongue" phenomenon. Journal of Verbal Learning and Verbal Behavior, 5(4), 325-337.
Charles, S. T., Mather, M., \& Carstensen, L. L. (2003). Aging and emotional memory: the forgettable nature of negative images for older adults. Journal of Experimental Psychology: General, 132(2), 310-324.

Cho, J. Y. (2007). Elderly memory disorder scale. Seoul: Hakjisa.

Choi, J. S. (2008). Age of acquisition effects in word and picture naming in Korean (Master's thesis). Ewha Womans University, Seoul, Korea.

Christensen, K. J., Multhaup, K. S., Nordstrom, S., \& Voss, K. (1991). A cognitive battery for demantia: development and measurement characteristics. Psychological Assessment: A Journal of Consulting and Clinical Psychology, 3(2), 168.

Craik, F. I., \& Byrd, M. (1982). Aging and cognitive deficits: the role of attentional resources. In F. I. M. Craik \& S. Trehub (Eds.), Aging and cognitive processes (pp. 191-211). New York: Plenum.

Cuthbert, B. N., Schupp, H. T., Bradley, M. M., Birbaumer, N., \& Lang, P. J. (2000). Brain potentials in affective picture processing: covariation with autonomic arousal and affective report. Biological Psychology, 52(2), 95111.

Dillon, D. G., Cooper, J. J., Grent, T., Woldorff, M. G., \& LaBar, K. S. (2006). Dissociation of event-related potentials indexing arousal and semantic cohesion during emotional word encoding. Brain and Cognition, 62(1), 4357.

Estes, Z., \& Adelman, J. S. (2008). Automatic vigilance for negative words in lexical decision and naming: comment on Larsen, Mercer, and Balota (2006). Emotion, 8(4), 441-444.

Estes, Z., \& Verges, M. (2008). Freeze or flee? Negative stimuli elicit selective responding. Cognition, 108(2), 557-565.

Feyereisen, P. (1997). A meta-analytic procedure shows an age-related decline in picture naming: comments on Goulet, Ska, and Kahn (1994). Journal of Speech, Language, and Hearing Research, 40(6), 1328-1333.

Fox, L. S., \& Knight, B. G. (2005). The effects of anxiety on attentional processes in older adults. Aging \& Mental Health, 9(6), 585-593.

Glickman, M. E., Gray, J. R., \& Morales, C. J. (2005). Combining speed and accuracy to assess error-free cognitive processes. Psychometrika, 70(3), 405-425.

Griffin, Z. M., \& Bock, K. (1998). Constraint, word frequency, and the relationship between lexical processing levels in spoken word production. Journal of Memory and Language, 38(3), 313-338.

Hauk, O., Rockstroh, B., \& Eulitz, C. (2001). Grapheme monitoring in picture naming: an electrophysiological study of language production. Brain Topography, 14(1), 3-13. 
Hinojosa, J. A., Méndez-Bértolo, C., Carretié, L., \& Pozo, M. A. (2010). Emotion modulates language production during covert picture naming. Neuropsychologia, 48(6), 1725-1734.

Huttenlocher, J., \& Kubicek, L. F. (1983). The source of relatedness effects on naming latency. Journal of Experimental Psychology: Learning, Memory, and Cognition, 9(3), 486-496.

Ihssen, N., Heim, S., \& Keil, A. (2007). The costs of emotional attention: affective processing inhibits subsequent lexico-semantic analysis. Journal of Cognitive Neuroscience, 19(12), 1932-1949.

Indefrey, P., \& Levelt, W. J. (2004). The spatial and temporal signatures of word production components. Cognition, 92(1-2), 101-144.

Isaacowitz, D. M., Toner, K., Goren, D., \& Wilson, H. R. (2008). Looking while unhappy: mood-congruent gase in young adults, positive gaze in older adults. Psychological Science, 19(9), 848-853.

Jo, M. J., Bae, J. N., Seo, K. H., Ham, B. J., Kim, J. K., Lee, D. W., \& Kang, M. H. (1999). Validation of geriatric depression scale, Korean version (GDS) in the assessment of DSM-III-R major depression. Journal of Korean Neuropsychiatric Association, 38(1), 48-62.

Kahan, T. A., \& Hely, C. D. (2008). The role of valence and frequency in the emotional Stroop task. Psychonomic Bulletin \& Review, 15(5), 956-960.

Kang, Y. (2006). A normative study of the Korean-Mini Mental State Examination (K-MMSE) in the elderly. The Korean Psychological Association, 25(2), 1-12.

Kang, Y., Na, D. L., \& Hahn, S. H. (1997). A validity study on the Korean MiniMental State Examination (K-MMSE) in dementia patients. Journal of the Korean Neurological Association, 15(2), 300-308.

Kang, Y., Jang, S. M., \& Na, D. L. (2012). Seoul Neuropsychological Screening Battery 2nd ed (SNSB-II). Seoul: Human Brain Research \& Consulting.

Kim, C. M. (2019). An effect for sequential information processing by the anxiety level and temporary affect induction. Journal of the Korea AcademiaIndustrial cooperation Society, 20(4), 224-231.

Kim, H. E. (2012). The relation of emotion, arousal, and perceptual complexity with emotional processing speed (Master's thesis). Chonnam National University, Gwangu, Korea.

Kim, H., \& Jin, Y. (2016). The effect of reward type on cognitive control in young and old adults. The Korean Journal of Developmental Psychology, 29(4), 37-59.

Kim, J. W., Hwang, J. H., Kim, S. L., \& Kim, H. H. (2013). Differences in attention and naming ability with age in the elderly. Journal of Speech \& Hearing Disorders, 22(3), 25-44.
Kousta, S. T., Vinson, D. P., \& Vigliocco, G. (2009). Emotion words, regardless of polarity, have a processing advantage over neutral words. Cognition, 112(3), 473-481.

Kuperman, V., Estes, Z., Brysbaert, M., \& Warriner, A. B. (2014). Emotion and language: valence and arousal affect word recognition. Journal of Experimental Psychology: General, 143(3), 1065-1081.

Laganaro, M., Morand, S., Schwitter, V., Zimmermann, C., Camen, C., \& Schnider, A. (2009). Electrophysiological correlates of different anomic patterns in comparison with normal word production. Cortex, 45(6), 697707.

Lang, P. J., Bradley, M. M., \& Cuthbert, B. N. (1997). International affective picture system (IAPS): technical manual and affective ratings. NIMH Center for the Study of Emotion and Attention, 1, 39-58.

Lang, P. J., Bradley, M. M., \& Cuthbert, B. N. (2005). International affective picture system (IAPS): affective ratings of pictures and instruction manual. Technical Report A-6. Gainesville, Florida: University of Florida.

Lee, E. J., Han, J. S., \& Sim, H. S. (2004). The effects of the phonetic complexity on the disfluencies and the articulation errors of people who stutter. Korean Journal of Communication Disorders, 9(3), 139-156.

Lee, H. H., \& Kang, Y. W. (2019). The positivity effect in memory in older adults with subjective cognitive decline: a comparison with normal elderly and patients with mild cognitive impairment. The Korean Journal of Developmental Psychology, 32(4), 21-44.

Lovelace, E. A., \& Twohig, P. T. (1990). Healthy older adults' perceptions of their memory functioning and use of mnemonics. Bulletin of the Psychonomic Society, 28(2), 115-118.

Mather, M., \& Carstensen, L. L. (2005). Aging and motivated cognition: the positivity effect in attention and memory. Trends in Cognitive Sciences, 9(10), 496-502.

McKenna, F. P., \& Sharma, D. (1995). Intrusive cognitions: an investigation of the emotional Stroop task. Journal of Experimental Psychology: Learning, Memory, and Cognition, 21(6), 1595-1670.

Mikels, J. A., Larkin, G. R., Reuter-Lorenz, P. A., \& Carstensen, L. L. (2005). Divergent trajectories in the aging mind: changes in working memory for affective versus visual information with age. Psychology and Aging, 20(4), 542-553.

Mortensen, L., Meyer, A. S., \& Humphreys, G. W. (2006). Agerelated effects on speech production: a review. Language and Cognitive Processes, 21(13), 238-290.

Nam, M. K., \& Bang, H. J. (2018). Positivity effect in selective attention and 
memory retrieval of emotional information among older adults. The Korean Journal of Developmental Psychology, 31(4), 99-122.

National Institute of Korean Language. (2015). Survey on the frequency of Korean use. Seoul: Author.

Nicholas, M., Obler, L., Albert, M., \& Goodglass, H. (1985). Lexical retrieval in healthy aging. Cortex, 21(4), 595-606.

Park, T. J. (2004). Cognitive neural mechanisms of aging. The Korean Journal of Cognitive and Biological Psychology, 16(3), 317-336.

Park, T. J., \& Park, S. H. (2009). Emotional evaluation about IAPS in Korean university students. The Korean Journal of Cognitive Science, 20(2), 183-195.

Pratto, F., \& John, O. P. (1991). Automatic vigilance: the attention-grabbing power of negative social information. Journal of Personality and Social Psychology, 61(3), 380-391.

Ramsay, C. B., Nicholas, M., Au, R., Obler, L. K., \& Albert, M. L. (1999). Verb naming in normal aging. Applied Neuropsychology, 6(2), 57-67.

Ratcliff, R., Thapar, A., Gomez, P., \& McKoon, G. (2004). A diffusion model analysis of the effects of aging in the lexical-decision task. Psychology and Aging, 19(2), 278-289.

Reed, A. E., Chan, L., \& Mikels, J. A. (2014). Meta-analysis of the age-related positivity effect: age differences in preferences for positive over negative information. Psychology and Aging, 29(1), 1-15.

Russell, J. A. (2003). Core affect and the psychological construction of emotion. Psychological Review, 110(1), 145-172.

Russell, J. A., \& Barrett, L. F. (1999). Core affect, prototypical emotional episodes, and other things called emotion: dissecting the elephant. Journal of Personality and Social Psychology, 76(5), 805-819.

Salthouse, T. A. (1996). The processing-speed theory of adult age differences in cognition. Psychological Review, 103(3), 403-428.

Samanez-Larkin, G. R., Robertson, E. R., Mikels, J. A., Carstensen, L. L., \& Gotlib, I. H. (2009). Selective attention to emotion in the aging brain. Psy- chology and Aging, 24(3), 519-529.

Schmitter-Edgecombe, M., Vesneski, M., \& Jones, D. W. R. (2000). Aging and word-finding: a comparison of spontaneous and constrained naming tests. Archives of Clinical Neuropsychology, 15(6), 479-493.

Snodgrass, J. G., \& Vanderwart, M. (1980). A standardized set of 260 pictures: norms for name agreement, image agreement, familiarity, and visual complexity. Journal of Experimental Psychology: Human Learning and Memory, $6(2), 174-215$.

Sung, J. E., \& Kim, J. K. (2011). Differential performance on generative naming and typicality rating between young and older adults: a preliminary study to develop a semantic complexity-based naming treatment for persons with neurogenic communication disorders. Journal of Speech \& Hearing Disorders, 20(1), 31-49.

Thomas, R. C., \& Hasher, L. (2006). The influence of emotional valence on age differences in early processing and memory. Psychology and Aging, 21(4), 821-825.

Vinson, D., Ponari, M., \& Vigliocco, G. (2014). How does emotional content affect lexical processing?. Cognition \& Emotion, 28(4), 737-746.

Vitkovitch, M., \& Tyrrell, L. (1995). Sources of disagreement in object naming. The Quarterly Journal of Experimental Psychology Section A, 48(4), 822-848.

Wood, S., Kisley, M. A. (2006). The negativity bias in eliminated in older adults: age-related reduction in event-related brain potentials associated with evaluative categorization. Psychology and Aging, 21(4), 815-820.

Wolf, M., \& Segal, D. (1992). Word finding and reading in the developmental dyslexias. Topics in Language Disorders, 13(1), 51-65.

Yap, M. J., \& Seow, C. S. (2014). The influence of emotion on lexical processing: Insights from RT distributional analysis. Psychonomic Bulletin \& Review, 21(2), 526-533. 
Appendix 1. list of stimuli

\begin{tabular}{lcc}
\hline 긍정 & 부정 & 중립 \\
\hline 고양이 & 거미 & 버섯 \\
토끼 & 개 & 컵 \\
사자 & 곰 & 바구니 \\
기차 & 상어 & 수건 \\
피자 & 거북이 & 의자 \\
골프 & 망치 & 버스 \\
말 & 뱀 & 선풍기 \\
나비 & 쥐 & 다리미 \\
호랑이 & 총 & 포크 \\
돌고래 & 신발 & 트럭 \\
아기 & 쓰레기 & 우산 \\
풍선 & 칼 & 시계 \\
케이크 & 해골 & 접시 \\
\hline
\end{tabular}




\title{
국문초록
}

\author{
시각적 자극의 정서가(Emotional Valence)에 따른 노년층의 대면이름대기 능력 \\ 김신희 · 성지은 \\ 이화여자대학교 대학원 언어병리학과
}

배경 및 목적: 이 연구의 목적은 정서가 정상 노년층과 청년층의 대면이름대기에 미치는 영향을 살펴보는 것이다. 방법: 본 연구의 대상 자는 총 60 명(노년 30명, 청년30명)이다. 본 연구에서는 대면이름대기 과제의 자극으로 IAPS 사진을 이용하였다. 결과: 대면이름대기 과 제에서 두 집단 간 정반응률 및 반응시간의 차이가 유의하였으며, 노년층이 청년층보다 유의하게 낮은 이름대기 능력과 긴 이름대기 시 간을 보이는 것으로 나타났다. 또한 정서가에 따른 정반응률 및 반응시간의 차이가 유의했으며, 중립범주에 비해 정서범주(긍정, 부정) 에서 정반응률이 낮았다. 반응시간의 차이는 세 정서범주 모두에서 유의하였으며 중립<긍정<부정의 순서로 긴 반응시간을 보였다. 또한 집단과 정서가에 대한 이차상호작용이 유의하였으며 이는 부정범주에서 노년층의 정반응률이 낮아지는 것과, 부정, 긍정 범주에 서 노년층의 반응시간이 길어지는 것에 기인한다. 논의 및 결론: 청년층과 노년층 모두, 중립정서 범주보다 정서범주(긍정, 부정)에서 낮 은 정반응률과 길어진 반응시간을 보여, 정서자극이 이름대기 수행을 방해하는 것으로 나타났으며, 그 영향이 노년층에게 더 큰 것으 로 나타났다. 이는 노년층이 노화로 인한 처리 자원의 감소 및 주의력 감퇴로 인해 정서에 의한 간섭의 영향을 더 크게 받은 것으로 해석 된다. 또한 정서자극에 대한 노년층의 증가된 주의편향에 의한 결과일 수 있음을 제안한다.

핵심어: 대면이름대기, 정서가, 노화

본 연구는 대한민국 교육부와한국연구 재단의 지원을 받아 수행된 연구임(No. NRF-2019R1A2C1089280).

본 논문은 제1저자의 석사학위논문을 발췌 및 수정한 것임.

\section{참고문헌}

강연욱 (2006). K-MMSE(Korean-Mini Mental State Examination)의 노인 규준 연구. 한국심리학회지, 25(2), 1-12.

강연욱, 나덕렬, 한승혜 (1997). 치매 환자들을 대상으로 한 K-MMSE의 타당도 연구. 대한신경과학회지, 15(2), 300-308.

강연욱, 장승민, 나덕렬 (2012). 서울신경심리검사2 판(SNSB-II). 인천: 휴브알엔씨.

국립국어연구원 (2005). 현대 국어 사용 빈도 조사 2. 서울: 국립국어연구원.

김정완, 황재호, 김수련, 김향희 (2013). 정상 노인의 연령에 따른 주의력 및 이름대기 능력의 차이. 언어치료연구, 22(3), 25-44.

김충명 (2019). 불안수준 및 일시적 유발정서가 서열정보 어휘처리에 미치는 효과. 한국산학기술학회 논문지, 20(4), 224-231.

김현옥, 진영선 (2016). 보상 유형이 인지적 통제에 미치는 연령차. 한국심리학회지: 발달, 29(4),37-59.

김희은 (2012). 정서가, 각성수준 및 지각적 복잡성과 정서처리속도의 관계. 전남대학교 대학원 석사학위논문.

남미경, 방희정 (2018). 노인의 정서 정보에 대한 선택적 주의와 기억 인출의 긍정성 효과. 한국심리학회지: 발달, 31(4), 99-122.

박태진 (2004). 노화의 인지신경기전. 한국심리학회지: 인지 및 생물, 16(3), 317-336.

박태진, 박선희 (2009). IAPS 자극에 대한 한국 대학생의 정서 평가. 인지과학, 20(2), 183-195.

성지은, 김진경 (2011). 청년층과 노년층 간 생성이름대기에서 나타난 범주별 전형성 비교: 의미복잡성 이론에 근거한 이름대기 치료 프로토콜 개발 예

비 연구. 언어치료연구, 20(1), 31-49.

이은주, 한진순, 심현섭 (2004). 조음복잡성이 비유창성과 조음오류에 미치는영향 언어청각장애연구, 9(3), 139-156.

이현호, 강연욱 (2019). 주관적 인지저하 노인들의 기억의 긍정성 효과: 정상 노인 및 경도인지장애 환자와의 비교. 한국심리학회지: 발달, 32(4), 21-44.

조맹제, 배재남, 서국희, 함봉진, 김장규, 이동우, 강민희 (1999). DSM-III-R 주요우울증에 대한 한국어판 Geriatric Depression Scale (GDS)의 진단적 타당성 연구. 신경정신의학, 38(1), 48-63. 
최정선 (2008). 습득연령이 단어명명과제와 그림명명과제에 미치는 영향. 이화여자대학교 대학원 석사학위논문.

최진영 (2007). 노인 기억장애 검사. 서울: 학지사.

\section{ORCID}

김신희(제1저자, 대학원생 https://orcid.org/0000-0001-9540-2771); 성지은(교신저자, 교수 https://orcid.org/0000-0002-1734-0058) 